\begin{tabular}{|c|l|}
\hline Title & Synthesis of (Fluoroal kyl)amines by Deoxyfluorination of A mino A Icohols \\
\hline Author(s) & Nomoto, Takashi; Fukuhara, Tsuyoshi; Hara, Shoji \\
\hline Citation & $\begin{array}{l}\text { Synlett, 2006(11), 1744/1746 } \\
\text { https://loi.org/10.1055/s 2006-947316 }\end{array}$ \\
\hline Issue Date & 2006 \\
\hline Doc URL & http://hdl.handle.net/2115/14582 \\
\hline Type & article \\
\hline File Information & Synlett11.pdf \\
\hline
\end{tabular}

Instructions for use 


\section{Synthesis of (Fluoroalkyl)amines by Deoxyfluorination of Amino Alcohols}

Takashi Nomoto, Tsuyoshi Fukuhara, and Shoji Hara*

Graduate School of Engineering, Hokkaido University, Sapporo, 060-8628 J apan

Abstract: Deoxyfluorination of amino alcohols was achieved using $N, N$-diethyl- $\alpha, \alpha$-difluorobenzylamine (DFBA) to furnish $N$-benzoyl(fluoroal kyl)amines selectively.

Key words: amino alcohols, fluorination, deoxygenation, substitution, $N, N$-diethyl- $\alpha, \alpha$-difluorobenzylamine

Introduction of fluorine atoms into biologically active amines ${ }^{1}$ and amino acids $^{2}$ is of great interest to medicinal chemists because the fluorine atom reduces the basicity of the amino group and modifies their metabolism and pharmacological properties. Furthermore, due to the development of $18 \mathrm{~F}$-labeled compounds for positron emission tomography (PET), 3 the importance of the (fluoroalkyl)amine synthesis has increased remarkably.

Fluoroamines can be prepared from amino al cohols via cyclic sulfamidates; ${ }^{4}$ however, it includes multi-step procedures and requires a long reaction time. Due to the short half-life of $18 \mathrm{~F}, 5$ it is desirable to synthesize them as rapidly as possible, and a more direct method is required. Though the deoxyfluorination reaction of amino alcohols is the most suitable method for their synthesis, the application of deoxyfluorination reagents, such as diethylaminosulfur trifluoride (DAST)4e,6 or bis(2-methoxyethyl)aminosulfur trifluoride (Deoxofluor $\left.{ }^{\mathrm{TM}}\right),{ }^{7}$ often results in undesired side reactions. Recently, we reported the deoxyfluorination reactions of alcohols, 8 diols, 9 aldehydes, ${ }^{10}$ and epoxides ${ }^{11}$ using $(N, N$-diethyl- $\alpha, \alpha$-difluoro-( $m$-methyl benzyl)amine (DFMBA). We wish to report here that amino alcohols can be directly converted to $N$-benzoyl(fluoroalkyl)amines by $N, N$-diethyl- $\alpha, \alpha$-difluorobenzylamine (DFBA).12

When 2-(phenylamino)ethanol (1a) was allowed to react with 2.4 equival ents of DFBA without solvent at $70{ }^{\circ} \mathrm{C}$ using conventional oil bath heating or microwave irradiation, the reaction was complete in 10 minutes and $N$-(2-fluoroethyl)- $N$-phenylbenzamide (2a) was obtained in $85 \%$ yield. ${ }^{14} \mathrm{~A}$ 
hydroxyl group in la was converted to a fluoride while an amino group was acylated by DFBA. The reaction must proceed through an oxazolinium intermediate 3 as in the case of diols. ${ }^{9}$ It was supported by the formation of oxazoline derivative 4 in the reaction of 2 -aminoethanol with DFBA (Scheme $1)$.

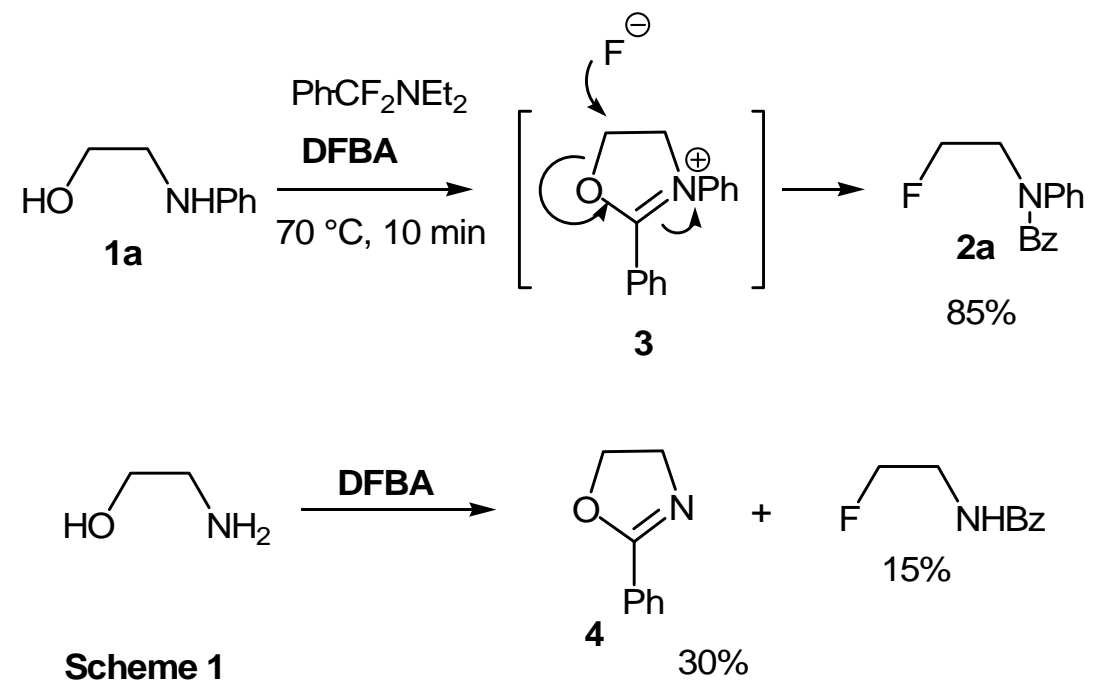

2-(Benzylamino)ethanol (1b) was less reactive than la and the corresponding (fluoroalkyl)amine ( $2 \mathrm{~b}$ ) was obtained in $70 \%$ yield by reaction with DFBA at $100{ }^{\circ} \mathrm{C}$ for ten minutes (Table 1 ). The fluorination of sec-hydroxy group of the amino alcohols 1c-e by DFBA also proceeded to give the corresponding (fluoroalkyl)amines $2 \mathrm{c}$-e in good yields. Fluorination of a $\gamma$-amino al cohol is also possible and 3-(benzylamino)-1-porpanol (1f) could be converted to the corresponding $(\gamma$-fluoroalkyl)amide $2 f$ in $71 \%$ yield. In the reaction with cis-2-(benzylamino)cyclohexanol

(1g), $\mathrm{N}$-benzyl- $N$-(trnas-2-fluorocyclohexyl)benzamide (2g) was obtained in moderated yield and the formation of an olefinic by-product was observed. On the other hand, only a complex mixture was formed in the reaction of trans-2-(benzylamino)cyclohexanol with DFBA. When trans-2-(dibenzylamino)cyclohexanol (1h) was used, the fluorination took place with retention of the stereochemistry and $N, N$-dibenzyl(trans-2-fluorocyclohexyl)amine ( $2 \mathrm{~h}$ ) was obtained in high yield. In the case of $\mathrm{N}, \mathrm{N}$-disubstituted amino alcohols, the reaction must proceed through an aziridinium intermediate instead of the oxazolinium $3 .{ }^{15}$ 
Table 1 Fluorination of Amino Alcohols Using DFBA ${ }^{a}$

Amino alcohol Reaction conditions $100^{\circ} \mathrm{C}, 10 \mathrm{~min}$

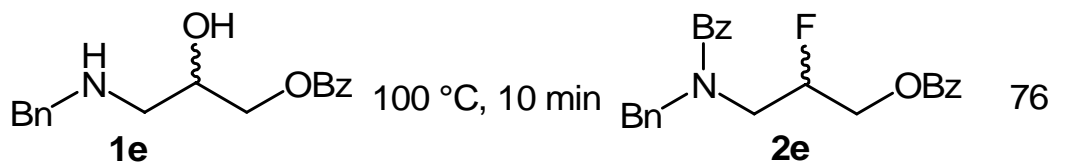<smiles>OCCCNCc1ccccc1</smiles><smiles>O=C(c1ccccc1)N(CCCF)Cc1ccccc1</smiles><smiles>OC1CCCCC1Br</smiles>
$100^{\circ} \mathrm{C}, 10 \mathrm{~min}$<smiles>CCCCC(C)(C)C</smiles><smiles>CCCCC1CCCC[C@@H]1O</smiles>

1h $100^{\circ} \mathrm{C}, 10 \mathrm{~min}$<smiles>OC[C@H](Br)NCc1ccccc1</smiles><smiles>OC[C@H](Br)NCc1ccccc1</smiles>

2g Bn<smiles>CCCCNC1CCCC[C@@H]1F</smiles>

94

2h<smiles>O=C(c1ccccc1)N(Cc1ccccc1)C(=O)c1ccccc1</smiles><smiles>O=C(c1ccccc1)N(Cc1ccccc1)C(Br)CF</smiles>

a) Unless otherwise stated, the reaction was carried out with DFBA (2.4 equiv) and $\mathbf{1}$ (1 equiv) without solvent.

b) Isolated yield base on 1 .

c) Dioxane was used as the solvent. 
Various optically active amino alcohols are easily accessible and can be converted into the corresponding optically active (fluoroalkyl)amines by DFBA. Thus, (S)- $N$-benzyl- $N$-(1-fluoromethyl-2-phenylethyl)benzamide (2k) and (S)- $N$-benzyl- $N$-(1-fluoromethyl-3-methylbutyl)benzamide (2l) could be prepared optically active from the corresponding optically active amino alcohols $1 \mathrm{k}$ and $1 \mathrm{l}$ in $78 \%$ and $86 \%$ yields, respectively.

Enantiomerically pure (S)- and ( $R$ )-(2-fluoro-1-methylethyl)amines (5) were required for the synthesis of $\beta$-adrenoceptor ligands, and were prepared from the corresponding 2-(benzylamino)-1-propanol (1j) in a multi-step synthesis via cyclic sulfamidates in $21 \%$ and $26 \%$ overall yields, respectively. ${ }^{4 e}$ When (S)- or $(R)$ - $1 \mathrm{j}$ was treated with 2.4 equivalents of DFBA at $100{ }^{\circ} \mathrm{C}$, the reaction was complete in 10 minutes and the corresponding (S)- or (R)-N-benzyl-N-(2-fluoro-1-methylethyl)benzamide (2j) was obtained in 84 and $86 \%$ yields, respectively. After removal of the protecting groups, the desired (S)- or (R)-(2-fluoro-1-methylethyl)amine (5) was obtained enantiomerically pure in $59 \%$ and $56 \%$ overall yields, respectively (Scheme 2).<smiles>C[C@@H](N)CF</smiles>

$(S)-5$<smiles>C[C@H](N)CF</smiles>

$(R)-5$

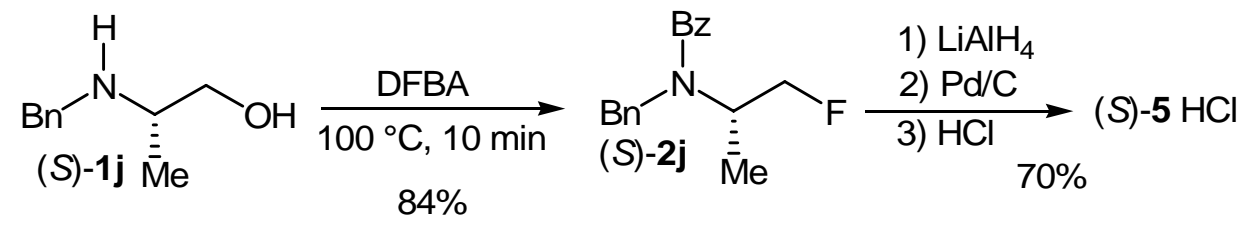

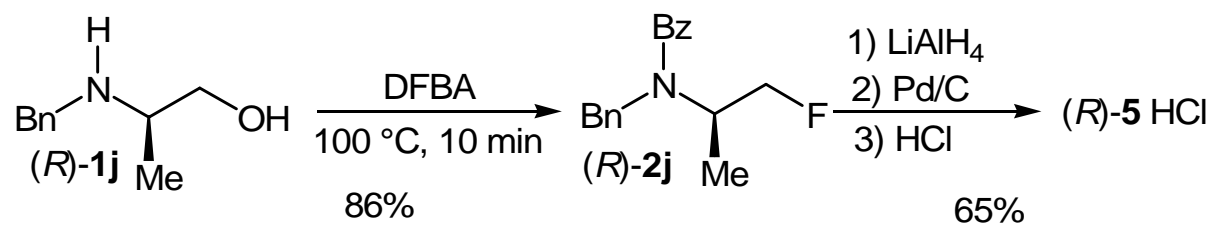

Scheme 2

References and notes.

(1) (a) Coutts, R. T.; Benderly, A.; Mak, A. L. C. J . Fluorine Chem. 1980, 16, 
277. (b) Kozikowski, A. P.; Wu, J .-P. Tetrahedron Lett. 1990, 31, $4309 . \quad$ (c) Schumacher, D. P.; Clark, J . E.; Murphy, B. L.; Fischer, P. A. J . Org. Chem. 1990, 55, 5291. (d) Dolensky, B.; Kirk, K. L. J. Org. Chem. 2001, 66, 4687. (e) Grunewald, G. L.; Romero, F. A.; Criscione, K. R. J. Med. Chem. 2005, 48, 1806.

(2) (a) Fluorine-containing Amino Acids, Kukhar, V. P.; Soloshonok, V. A. Eds.; Wiley: Chichester, 1995. (b) Qiu, X.-L.; Meng, W.-D.; Qing, F.-L. Tetrahedron 2004, 60,6711; and references cited therein.

(3) (a) Chi, D. Y.; Kilbourn, M. R.; Katzenellenbogen, J. A.; Welch, M. J J J Org. Chem. 1987, 52, 658. (b) Lyle, T. A.; Magill, C. A.; Pitzenberger, S. M. J. Am. Chem. Soc. 1987, 109, 7890. (c) Posakony, J . J .; Tewson, T. J. Synthesis, 2002, 766. (d) Bolton, R. J. Label Compd Radiopharm 2002, 45, 485. (e) Couturier, O.; Luxen, A.; Chatal, J .-F.; Vuillez, J .-P.; Rigo, P.; Hustinx, R. Eur. J. Nud. Med. Mol. Imaging 2004, 31, 1182.

(4) (a) White, G. J .; Garst, M. E. J . Org. Chem. 1991, 56, 3177. (b) Van Dort, M. E.; J ung, Y.-W.; Sherman, P. S.; Kilbourn, M. R.; Wieland, D. M. J. Med. Chem. 1995, 38, 810. (c) Ok, D.; Fisher, M. H.; Wyvratt, M.J .; Meinke, P. T. Tetrahedron Lett. 1999, 40, 3831. (d) Posakony, J. J .; Grierson, J. R.; Tewson, T. J . J. Org. Chem. 2002, 67, 5164. (e) Posakony, J . J .; Tewson, T. J . Synthesis 2002, 766. (f) McConathy, J.; Martarello, L.; Malveaux, E. J.; Camp, V. M.; Simpson, N. E.; Simpson, C. P.; Bowers, G. D.; Olson, J . J .; Goodman, M. M. J. Med. Chem. 2002, 45, 2240.

(5) The half-life of $18 \mathrm{~F}$ is about $110 \mathrm{~min}$.

(6) (a) Silverman, R. B.; Levy, M. A. J. Org. Chem. 1980, 45, 815. (b) Remuzon, P.; Bouzard, D.; Di Cesare, P.; Essiz, M.; J acquet, J . P.; Kiechel, J . R.; Ledoussal, B.; Kesseler, R. E.; Fung-Tomc, J . J . Med. Chem. 1991, 34, 29. (c) J onghe, S. D.; Overmeire, I. V.; Calenbergh, S. V.; Hendrix, C.; Busson, R.; Keukeleire, D. D.; Herdewijn, P. Eur. J. Org. Chem. 2000, 3177.

(7) Ye, C.; Shreeve, J . M. J. Fluorine Chem. 2004, 125, 1869.

(8) (a) Kobayashi, S.; Yoneda, A.; Fukuhara, T.; Hara, S. Tetrahedron Letters, 2004, 45, 1287. (b) Kobayashi, S.; Yoneda, A.; Fukuhara, T.; Hara, S. Tetrahedron, 2004, 60, 6923.

(9) Yoneda, A.; Fukuhara, T.; Hara, S. Chem. Commun. 2005, 3589.

(10) Furuya, T.; Fukuhara, T.; Hara, S. J. Fluorine Chem., 2005, 126, 721.

(11) Yu, H.-W.; Nakano, Y.; Fukuhara, T.; Hara, S. J. Fluorine Chem., 2005, 126, 962. 
(12) Due to the enolazable character of the amide function, 13 the NMR spectra of the $\mathrm{N}$-acylated products 2 were sometimes complicated and the reduction of the amide function to the amine was necessary for the analysis. When DFBA was used for the reaction with $N$-benzylamino alcohols, $\mathrm{N}, \mathrm{N}$-dibenzylamine derivatives were formed after the reduction, and their NMR spectra are simpler than that of the product from DFMBA. Therefore, DFBA was used instead of DFMBA. DFBA showed reactivity comparable with DF MBA and can be prepared from $\mathrm{N}, \mathrm{N}$-diethylbenzamide as DF MBA. ${ }^{10}$ (13) Stewart, W. E.; Siddall, III, T. H. Chem. Rev. 1970, 70, 517.

(14) To a reactor of a Teflon ${ }^{\mathrm{TM}}$ PFA tube with a diameter of $10 \mathrm{~mm}$ sealed at one end, 1a (137 mg, $1 \mathrm{mmol}$ ) and DFBA (478 mg, $2.4 \mathrm{mmol}$ ) were introduced. The open end of the reactor was connected to a reflux condenser. Then, the reactor part was submitted to microwave-irradiation (IDX microwave oven for organic synthesis IMCR-25003) for $10 \mathrm{~min}$ and during the irradiation, the temperature was kept at $70{ }^{\circ} \mathrm{C}$. After cooling, the reaction mixture was poured into an aq $\mathrm{NaHCO}_{3}$ solution. The product was extracted with $\mathrm{Et}_{2} \mathrm{O}$ (3X) and the combined ethereal layers were dried over $\mathrm{MgSO}_{4}$. Purification by column chromatography (silica gel/hexane $\mathrm{Et}_{2} \mathrm{O}$ ) gave $2 \mathrm{a}$ ( $207 \mathrm{mg}, 0.85$ $\mathrm{mmol}$ ) in $85 \%$ yield.

$N$-(2-Fluoroethyl)- $N$-phenyl benzamide (2a): IR (neat): 1649, 1494, $1377 \mathrm{~cm}^{-1}$. 1H NMR: $\delta=7.32-7.09(\mathrm{~m}, 10 \mathrm{H}), 4.76(\mathrm{dt}, J=47.6,4.9 \mathrm{~Hz}, 2 \mathrm{H}), 4.20(\mathrm{dt}$, J = $25.6,4.9 \mathrm{~Hz}, 2 \mathrm{H}) .{ }^{13} \mathrm{C}$ NMR: $\delta=170.94,144.08,135.80,129.94,129.31(2 \mathrm{C})$, 128.90 (2C), 127.89 (2C), $127.83(2 \mathrm{C}), 126.91,81.52$ (d, J = 168.7 Hz), 51.57 (d, $J=20.7 \mathrm{~Hz}) . \quad{ }^{19 F} \mathrm{NMR}: \delta=-222.60--222.98(\mathrm{~m}, 1 \mathrm{~F}) . \quad$ HRMS $(\mathrm{EI}): \mathrm{m} / \mathrm{z}$ cald for $\mathrm{C}_{15} \mathrm{H}_{14} \mathrm{NOF}: 243.1059$; found: 243.1057 .

(S)-1-Fluoro-2-aminopropane Hydrochloride (S)-(5)-HCl: White solid; $\mathrm{mp}$ 123-124 ${ }^{\circ} \mathrm{C}\left(\mathrm{lit}{ }^{4 \mathrm{e}} 127-127.5^{\circ} \mathrm{C}\right) ;[\alpha]^{21} \mathrm{D}+12.4(c 1.01, \mathrm{MeOH})\left\{\mathrm{it}^{4 \mathrm{e}}[\alpha]^{23} \mathrm{D} \quad+12.7\right.$ (c 1.01, MeOH) \}. (R)-MTPA amide of (S)-5 19F NMR: $\delta=-69.54(\mathrm{~s}, 3 \mathrm{~F})$, -232.36 (dt, J =26.2, 47.0 Hz, 1F).

(R)-1-Fluoro-2-aminopropane Hydrochloride $(R)-(5)-\mathrm{HCl}$ : White solid; $\mathrm{mp}$ 123-124.5 ${ }^{\circ} \mathrm{C}$ (lit.4e $127-128{ }^{\circ} \mathrm{C}$ ); $[\alpha]^{22 \mathrm{D}}-13.7$ (c 1.00, MeOH) \{it. $4 \mathrm{e}[\alpha]^{23 \mathrm{D}}-14.9$ (c 1.10, $\mathrm{MeOH}$ )\}. (R)-MTPA amide of $(R)-5$; $19 \mathrm{~F} \mathrm{NMR:} \delta=-69.47(\mathrm{~s}, 3 \mathrm{~F})$, -232.73 (dt, $J=26.2,47.0 \mathrm{~Hz}, 1 \mathrm{~F}$ ).

(15) Charvillon, F. B.; Amouroux, R. Tetrahedron Lett. 1996, 37, 5103. 